\title{
ACQUIRING ESP TEACHER COMPETENCE THROUGH THEORY AND PRACTICE
}

\author{
Eleonora Olivia Bălănescu*, ORCID ID: 0000-0002-8836-1331 \\ University of Craiova, 13 A. I. Cuza St, Craiova, Romania \\ *olivia.balanescu@edu.ucv.ro
}

Received: 03.18.2021

Accepted: 04.22.2021

\begin{abstract}
The emergence of English for Specific Purposes (ESP), which is closely linked to particular professions, requires qualified language teachers. Despite the growing demand for courses in ESP in Romania, and the eagerness of universities and private institutions to include these courses in their curricula, insufficient attention has been given to teaching training in this domain. In the absence of under-graduate ESP teacher training programmes, ESP is taught by General English graduates who basically learn as they go. The aim of this paper is to map the territory, that is, to outline the main coordinates on which a framework of ESP teacher training can be developed in Romania. These coordinates refer to the particularities of teaching ESP and to the subsequent teaching practice. The research method consists in combining theoretical considerations with practical advice and suggestions for pre-service teachers.
\end{abstract}

Key words: learner-centred approach, needs analysis, networking, teaching practice, training.

Rezumat. Emergenţa limbii engleze pentru scopuri specifice (ESP), care este în strânsă legătură cu anumite profesii, necesită profesori de limbă calificaţi. În pofida cererii crescute de cursuri în domeniul ESP în România și a disponibilităţii din partea universităţilor și a instituţiilor private de a include aceste cursuri în aria lor curriculară, o insuficientă atenţie a fost acordată pregătirii profesorilor în acest domeniu. În absenţa unor programe universitare, la nivel de licenţă, de pregătire a profesorilor de ESP, această materie este predată de către absolvenţi de Engleză Generală care învaţă să predea „din mers”. Obiectivul acestei lucrări este de a cartografia teritoriul, adică de a contura principalele coordonate pe baza cărora s-ar putea dezvolta un curs de pregătire a profesorilor în domeniul ESP în România. Aceste coordonate se referă la particularităţile predării ESP și la practica pedagogică adiacentă. Metoda de cercetare constă în combinarea consideraţiilor teoretice cu sfaturi și sugestii practice pentru viitorii profesori.

Cuvinte cheie: abordare centrată pe student, analiza nevoilor de învăţare, practică pedagogică, relaţionare, training. 


\section{Introduction}

The end of the communist regime in Romania marked the beginning of the nation's great political and cultural openness to the international world. People were free to travel, to communicate, to work and study abroad. At the same time, numerous foreign companies set up subsidiaries or started new businesses in the country, employing local workforce. As a result, there emerged a distinctive group of people who needed to communicate in English for very specific, job-related purposes. In the 1990s, the Romanian academic system was quick to react to these new learning needs and introduced courses of English for Specific Purposes (ESP) in their curricula. The education private sector also identified the 'gaps' on the market and, subsequently, private language schools began to offer English courses for Romanian employees in multinationals companies.

Since the demand for ESP courses has grown over the years, more and more teachers have been involved in teaching ESP. It is surprising that, in spite of the great demand and offer of ESP courses, most teachers are not adequately trained for teaching this branch of English, because there are not under-graduate ESP teacher-training programmes in Romania. Traditional language teaching has mainly focused on developing learners' linguistic competence, that is, their listening, speaking, reading and writing skills. English teachers are trained to do this job during their university studies in linguistics or literature. The experience that General English (GE) graduates can get during their methodology training course in university is often limited to teaching a few classes in secondary schools or high schools, as part of their teaching practice sessions under supervision, and thus, they are not adequately "equipped" with the skills required to face the difficulties one encounters when teaching English to Business or Engineer students in colleges. Many of them panic when they meet their first ESP class. In time, however, they get experience and have the possibility to develop their ESP competences by attending, as the author did, ESP teacher training courses organised by universities or the British Council Romania, or by registering for post-graduate programmes of continuous professional development and training.

The present paper argues for the necessity of creating systematic and effective ESP teacher training programmes in Romanian universities. We believe that these programmes will help pre-service teachers develop their ESP teacher competence which relies on fieldspecific language knowledge and ESP pedagogical skills. In what follows, we shall outline the two main coordinates of such a programme: theoretical knowledge required for teaching ESP and relevant teaching practice. Therefore, the first part will offer a review of the current issues in ESP instruction, emphasising the main aspects that make ESP teaching different from GE teaching, while the second part will approach the teaching practice stage, in terms of its organisation, objectives and outcome.

\section{GE vs. ESP Teaching Training}

The famous saying "Tell me what you need English for and I will tell you the English that you need" can be considered the main guiding principle of ESP [1]. This has determined a more thorough study of the language and of the teaching methods, bringing about a new linguistic approach. Unlike students of GE, students of ESP have a clear goal for learning, and the courses should be designed based on an analysis of their learning needs. From this perspective, the purpose of learning English represents the most obvious difference between GE and ESP. 
Another significant difference refers to the target discourse, which involves both the characteristics of the language that has to be taught and of the professional community in which the language will be used. Whereas a GE teacher is familiar with the target discourse because he/she has been trained in that discourse, the ESP teacher needs to impart fieldspecific language knowledge that may be largely unknown to him/her. Referring to Business English, Harmer points out that students need to study the kind of language that would enable them to operate in the world of English-medium commerce. They need to study specific vocabulary and language contexts which are less likely to occur in a GE course. Therefore, teachers should acquire specialist subject knowledge in order to "train classes in such procedures as the art of negotiating, the correct use of phone and e-mail, or the reading of business reports" [2].

Starting from the general assumptions about ESP made by Hutchinson and Waters [1 - 2], it should be stressed that:

a) ESP does not consist of teaching and learning "specialised varieties" of English. Although it is true that the sentence grammar of ESP tends to favour particular forms, such as the Present Tense Simple or passive constructions, there are no forms that cannot be found in General English.

b) Despite the key role of lexis in ESP courses, it is not possible to reduce ESP solely to specific vocabulary used in, say, business meetings or negotiations; it implies the investigation of the way business words are used in communication, and also of the skills and knowledge that enable people to use them.

c) ESP teaching is not different from other forms of language teaching. The content may vary, but the learning process is the same. In other words, there is not an ESP methodology as such, but rather methodologies that can be applied to ESP classes. From this perspective, ESP is not seen as a "product", but as an "approach", based on students' needs.

Once the common ground of GE and ESP has been established, teacher trainees should get familiar with the particularities of teaching ESP, the tasks they are supposed to fulfil, and the multiple roles they will have to perform. Perhaps the first and most valuable information they should get is that they will learn many new things that they did not study during their university years.

\section{Guidelines for Teaching ESP}

\subsection{Needs Analysis}

As mentioned above, needs analysis is the main feature of ESP courses. It is known that learners study a language because they have certain personal needs, learning needs and professional needs. Sprat suggests that: "Meeting these learner needs is part of being a good teacher" [3]. However, what makes ESP different is not "the existence of a need as such, but rather an awareness of the need" [1 - 3].

A needs analysis typically takes place in the classroom, involving the teacher and the learners. The following points have to be considered when conducting this kind of analysis:

- Teachers should collect and analyse information about what the students need to know (target needs) and what they already know. The information gap between the two represents the basis for future training.

- Some useful information gathering procedures are: written questionnaires or tests, oral interviews, observation during class activities. 
- It is common practice for ESP teachers to do a needs analysis at the beginning of the course, yet this should be an ongoing process because a teacher "will always have to adapt to new information and new perspectives as the course progresses" [4].

- Teachers must be aware that needs analyses may not always provide useful information. Scrivener lists some of the reasons for this phenomenon: students may not take the task seriously, and consequently offer little or no information at all, or even information that is not true [5]. There are cases when students do not know what they want or need to study, or they consider it is not their responsibility to think about this matter. In these situations, teachers need to explain to students that learning is not a product, but a process that needs to be negotiated, remade and periodically adjusted.

In order to be complete, the needs analysis should also take place outside the classroom, and involve dialogues with other stakeholders who can provide useful information and advice with reference to the above-mentioned gap. This type of investigation relies on discussions with other trainers, colleagues and supervisors, people who work in the target situation, or even former students who can inform on how much the English course they had once taken has helped them at their workplace. The teacher can also collect information from reading specialist subject books, methodology guides, ESP journals etc.

Discussing the importance of analysing the target situation, Frendo refers to the concepts of "discourse community", first introduced by John Swales, and "the Community of Practice", made popular by Étienne Wenger [6]. Frendo explains that the teacher needs to understand the community their students will work in, by paying attention to its discourse: what language is used and considered appropriate in that particular community. When they start working, the students will be part of a Community of Practice, which is basically a group of professionals/colleagues who, by working together, develop typical behaviours and ways of doing things. The teacher should collect data related to these communities in order to establish what to focus on in the class.

\subsection{Course Design}

Based on the data collected from the needs analysis, the ESP teacher has to "produce an integrated series of teaching-learning experiences" [1-4], that is, design a course that will meet the students' needs, with the aim of "filling" that gap between what the students know and what they are expected to know in order to function in the target situation. If in the 1990s, ESP materials were hard to find in Romania, and teachers had to design their own teaching materials, nowadays, the wide range of language coursebooks available on the market covers virtually all areas of ESP and all levels of proficiency. The role of the teacher is less to design materials, but to evaluate and select the ones appropriate for his/her classes.

For teacher trainees, using the syllabus set down by a coursebook has a number of advantages:

- it is what teachers use in class;

- it provides a framework within which trainees lessons will be planned;

- it provides learning continuity and progression for both trainees and students;

- it includes tried materials and activities;

- it is often accompanied by CDs and student workbooks; 
- it helps the course tutor/mentor who does not have to spend much time devising guidelines.

There are also a number of objections to using a coursebook:

- it prevents teachers, especially trainees, from exploring diverse materials;

- teachers rely on the course book without questioning the material;

- it may not meet the students' needs;

- in the case of teacher trainees, it may not provide the adequate material for them to practise certain teaching techniques.

Regarding the content of an ESP course, the teaching perspectives have changed over the years. Thus, in the 1970s, courses were language-oriented, the focus being on teaching specialised vocabulary and grammar.

The late 1970s and 1980s witnessed a major turn from linguistic competence to communicative competence, and communication skills became the target of ESP teaching. In the past years, lexis has come back into focus and is regarded as an essential part of any ESP course [2 - 4].

Students need to understand and master professional terminology in order to communicate efficiently with/as specialists.

Block points out that many researchers have focused on creating lists of technical vocabulary which can be useful when designing ESP courses. Coursebook authors have the possibility to design materials based on corpus studies into authentic spoken and written texts.

These corpus studies identify high-frequency language elements: specialised lexical items, professional collocations and phrases, acronyms and abbreviations used in a particular domain [3 - 4]. Discussing the relevance of highly frequent words for didactic purposes, Thornbury explains that "the relative frequency of a word is a key factor in determining its inclusion in a syllabus. The argument for teaching the most frequent words in the language is a powerful one. It is claimed that the most frequent words express the most frequent meanings in the language" [7].

In order to successfully use authentic materials in class, teachers need to acquire a basic level of specific knowledge in their students' academic subject.

This can be achieved through instruction during the training period and selfinstruction, which, useful as they may be, often prove insufficient to prepare teachers for classroom demands [8].

While Hutchinson and Waters argue that ESP teachers "have to struggle to master language and subject matter beyond the bounds of their previous experience" [1 - 5], other researchers consider that teachers have to "understand the nature of the material of the ESP specialism" [9], rather than "struggle" to acquire a high level of subject knowledge.

The degree of "struggling" depends on the general accessibility of the subject domain. Fields such as medicine and economics are familiar to many people as they are connected to personal experiences or public debates, whereas subjects such as chemistry or engineering, by their technical nature, are perceived as posing severe linguistic barriers.

From the author's experience, the teacher can rely on the students' subject knowledge, thus making them 'partners' in the process of teaching/learning and increasing their motivation to engage in genuine communication in the class.

The teacher acts as a language consultant, accepting equal status with the learners who have authority on subject knowledge. 


\subsection{Networking}

Since teachers cannot be expected to become experts in the subject matter, collaboration with subject specialists becomes essential to efficient ESP classes and programmes. Collaboration can take different forms:

- specialised information and advice that ESP teachers receive from subject teachers;

- the joint work of ESP and subject teachers to design appropriate syllabuses and teaching/learning activities;

- team-teaching - ESP and subject teachers work together in the classroom, teaching the class simultaneously.

The ESP teacher and the subject teacher need complementary, not overlapping roles in their collaboration relationship. Hutchinson and Waters underline this idea, showing that "the subject specialist can help the ESP teacher in learning more about the learners' target situation", while "the ESP teacher can make the subject specialist more aware of the language problems learners face" [1 - 6]. On the other hand, it is obvious that teachers' collaboration is likely to increase students' motivation as they see that their English course can directly be related to their subject course.

Networking in ESP also refers to the collaboration between language teachers. When faced for the first time with a business English course, for instance, the teacher should remember that other peers have taught that course before, so he/she does not have to spend a lot of time on searching or designing materials and classroom activities, because there is always a colleague around who can offer information and advice. At the same time, there is also the possibility of peer teaching with the aim of enhancing students' learning abilities.

\subsection{Methodological Approaches}

Hutchinson and Waters' famous definition of ESP as "an approach to language teaching in which all decisions as to content and method are based on the learner's reason for learning" [1 - 7] signalled the shift from the traditional teacher-centred approach to a learner-centred approach which enabled further development in language teaching. Maryellen Weimer explains that "in order to be learner-centered, instructional practice needs to change in five areas" [10] which refer to:

- the balance of power: teachers share the decision-making power with their students;

- the function of content: course content is dictated by learners' needs;

- the role of the teacher: instructors guide and facilitate learning;

- the responsibility for learning: students develop learning skills that will enable them to function as independent, autonomous learners;

- the process of evaluation: students are involved in self- and peer assessment activities, thus developing the skills needed by self-regulating learners.

Researchers agree that ESP is a course that accepts "many different approaches and a willingness to mix different types of materials and methodologies" [11]. In the classroom, teachers can use a variety of methodological approaches, depending on the type of ESP they are teaching, the needs of the students, and also their level of linguistic competence.

Starting from the assumption that the goal of an ESP course is to help students acquire the skills that they will need in their future work community, great emphasis has been placed on communicative language teaching, which has been very popular since the 
late 1970s. This approach is focused on the functional and communicative potential of language, working to develop learners' fluency, rather than their linguistic accuracy. Consequently, learning activities are selected according to how well they engage the learner in meaningful and authentic language use. For example, in a business English class, role plays are very useful, as they replicate the types of situations the students are likely to face in the future: business meetings, presentations, negotiations etc. In the late 1980s, Thomas Huckin argued that role plays "teach students simple social routines" and therefore are appropriate for lower levels, but "too simple for university students" [12]. He suggested instead the case study approach which is based on more elaborate problem-solving situations. Didactic case studies epitomise the learner-centred perspective and can be used with good results in teaching English for Medicine, Business or Law.

All in all, Marcu emphasises the idea that „based on the information gathered from the learners, taking into consideration their level of English, discussing and establishing the preferred methods for teaching and learning, both parties - teacher/trainer and learners embark on a journey with a specific end - that of becoming fluent speakers/users of the language" [13].

\section{Teaching Practice}

Apart from the theoretical course, teacher trainees need to observe and practise teaching. The main reason of having teaching practice is that teaching, like any other skill, cannot be learned without actually doing it. At the same time, As Boncea points out, it must not be forgotten that "training takes less to acquire and consolidate, it displays immediate results, whereas teaching implies deeper complexity, more stages and stretches over longer periods in producing results" [14].

An ESP training programme should consist of classroom observation and teaching practice. For instance, trainees will have to observe ten lessons taught by the mentor and twenty lessons taught by their peers, and teach five lessons. The organisation of the teaching practice depends on the training programme of which it is part and also on the institution which provides it. Generally we speak about:

- apprenticeship, which implies a teacher who has one or two trainees as "apprentices". These trainees observe the lessons taught by the teacher and teach some of the lessons, or parts of them.

- peer teaching, which refers to the situation in which one trainee takes the role of the teacher, while the students are his/her fellow trainees.

- microteaching, which refers to a time when the trainees do not teach a whole lesson, but only a part of it in order to practise one particular teaching technique, for example how to organise a groupwork activity.

Apprenticeship is the most used form of teacher training in Romania, therefore a future ESP teaching programme should also include the other two forms so as to ensure a complete framework for developing ESP teaching competence.

The classical procedure that trainers and trainees follow is based on six stages:

- the trainee and the trainer agree on what is to be taught;

- the trainee prepares a lesson plan;

- the lesson plan is discussed with the trainer and possibly with the other trainees;

- the trainer makes any necessary comments or changes to the plan;

- the trainee teaches the lesson;

- the trainer offers feedback. 


\subsection{ESP Teaching Practice Objectives and Outcome}

Teaching practice plays an important role in making ESP trainees aware of:

- how learners learn, what needs they have, and what skills they need;

- the language content of an ESP course;

- the language problems that students have;

- teaching techniques;

- classroom management skills.

The main objectives of ESP teaching practice would be one or several of the following:

- to allow trainees to observe real teaching;

- to give trainees the possibility to get in touch with real learners and their learning needs;

- to expose trainees to students of different levels of performance so that they understand the different approaches that are required;

- to provide trainees with opportunities to try out different teaching techniques under the trainer's supervision;

- to help trainees become increasingly more independent and able to take decisions in the classroom;

- to give feedback on the lessons being taught;

- to help trainees assess their own teaching and to get them accustomed to being observed;

- to make trainees aware of the responsibility they have for their students.

Just like an ESP course, the teacher training course should focus on learners' needs. Therefore, it generally offers trainees the opportunity to work on a variety of teaching skills. These skills are exercised in class or with other fellow trainees, first under the trainer's detailed guidance.

The trainer will tell trainees what to teach and which materials and techniques to use. This form of support will gradually be withdrawn as trainees gain in self-confidence and are able to identify students' language needs and to prepare adequate materials and activities to satisfy those needs.

The training course is definitely a time for experimenting. It is the only time that young teachers have to try out their ideas and get professional help and feedback. You try, you make mistakes, you reflect upon them, and you learn your lesson for your other future lessons. It is a fact that more is learned from lessons which do not go on very well, than from those which are successful.

Once teacher trainees gather some experience and master basic teaching techniques, they will be able to relax and to observe the students as the class is going on.

They will notice how their students are working individually and in pairs or groups, where they have problems etc.

At this stage, the young teachers will also be able to step back and look at their own performance with a critical eye. They will gradually become more aware of their strengths and weaknesses, and will know what needs to be changed in their teaching. The main aim of teaching practice is therefore to enable teacher trainees to become independent learners. 


\subsection{Team Work}

During teaching practice, trainees are expected to work in a team and help each other reach their common goal, that of acquiring the skills and techniques necessary in their future careers of ESP teachers. We believe that teaching practice is not a competition, but an opportunity for them to "grow" professionally with the aid of all the people involved in the programme, trainers and trainees alike.

There are many ways in which trainees can help each other [15]:

- They can exchange information about language, activities, resources, students.

- They can make suggestions for ways of designing or improving lesson plans.

- Before a class that a trainee has to teach, his/her colleagues may help with the equipment or the seats arrangement.

- After a class, they may take part in the post-observation sessions.

-When two trainees are teaching a class together, they should both prepare the lesson and evaluate it afterwards.

- If several trainees are supposed to teach the same group of students, they should keep the others informed as to what they did in a previous lesson and what they are going to do in the future, so that the lessons interrelate.

By working in teams, the teacher trainees become part of a community of practice, much like the communities their future students will integrate into. In this way, they will be aware of the mechanisms, the social and linguistic patterns of such communities, and will be able to rely on this awareness when analysing the learners' target needs.

\section{Conclusions}

An ESP training programme in Romania is meant to teach prospective teachers the particularities and requirements of ESP, along with the methods of designing their courses and adjusting their teaching to fulfil those requirements. From the beginning, they need to be ready to embrace new perspectives on language teaching and to be open to study new subjects so that they can get working knowledge of their students' field of studies. By the end of the training, the teachers will have gathered the necessary information about the importance of knowing their students from the data provided by a needs' analysis, the relevance of designing lessons that are meaningful for students' subjects and can help them acquire learning strategies and critical thinking skills, the necessity of permanently assessing their lessons to see whether the learners respond well to the input and can reach the learning objectives.

The practice stage is meant to enable teacher trainees to observe real teaching, to get in touch with ESP students, and to finally put into practice what they have learnt. Most trainees consider teaching practice the most valuable stage in the process of their professional training. Our argument is that this part of the programme teaches not just teaching, but the important role of collaboration and team work. It also teaches that one learns teaching by doing it and that it takes time to build and consolidate the necessary skills. In conclusion, learning teaching does not stop when the training course finishes; on the contrary, this is the moment when a teacher's development really begins.

\section{References}

1. Hutchinson T., Waters A. English for Specific Purposes. Cambridge: Cambridge University Press, 1994, pp. 8; $18 ; 53 ; 65 ; 160 ; 164 ; 19$.

2. Harmer J. The Practice of English Language Teaching. $3^{\text {rd }}$ edition. Harlow: Longman, 2003, pp. 10. 
3. Sprat M., Pulverness, A., Williams, M. The TKT Course. $2^{\text {nd }}$ edition. Cambridge: Cambridge University Press, 2005, pp. 57.

4. Block S., Lockwood, R.B., Frendo, E. The 6 Principles for Exemplary Teaching of English Learners: Academic and Other Specific Purposes. TESOL International Association, 2020, pp. 5.

5. Scrivener J. Learning Teaching. Oxford: Macmillan, 2005, pp. 71.

6. Frendo E. So You Want to Teach English for Specific Purposes? How not to Be A Muggle [online]. 2019. [accesat 22.02.2021]. Disponibil: https://eltabbjournal.com/teach-english-for-specific-purposes

7. Thornbury S. How to Teach Vocabulary. Harlow: Longman, 2002, pp. 35.

8. Boswood T., Marriot A. Ethnography for specific purposes. In: English for Specific Purposes, 1994, 13(1), pp. 321.

9. Harding, K. English for Specific Purposes. New York: Oxford, 2007, pp. 7.

10. Weimer M. Learner Centered Teaching. Five Key Changes to Practice. San Francisco: Jossey-Bass, 2002, pp. XVII.

11. Dudley-Evans T., ST John MJ. Developments in ESP: A Multi-disciplinary Approach. Cambridge: Cambridge University Press, 1998, pp. 30.

12. Huckin T.J. Achieving Professional Communicative Relevance in a 'Generalised' ESP Classroom. In: Chamberlain, D., Baumgardner, R.J., ed. ESP in the Classroom: Practice and Evaluation. Oxford: Modern English Publications and the British Council, 1988, pp. 61-71.

13. Marcu D. The Post-communist Era: "the bloom" of ESP in Romania. In: Revista de Ştiinţe Politice. Revue des Sciences Politiques, 2020, 66, pp. 117-126.

14. Boncea IJ. Teaching and Training Approaches during Technical English Classes. In: Analele Universităţii din Craiova. Seria Ştiinţe Filologice. Limbi Străine Aplicate. Anul IX, Nr. 1, Craiova: Universitaria, pp. 37-44.

15. Gower R., Phillips D., Walters S. Teaching Practice Handbook. London: Macmillan, 1995, pp. 5. 